De Jure : Jurnal Hukum dan Syari'ah

Vol. 8, No. 1, 2016, h. 15-23

Print ISSN: 2085-1618, Online ISSN: 2528-165

Available online at http://ejournal.uin-malang.ac.id/index.php/syariah

\title{
Hukuman Mati Bagi Tindak Pidana Narkoba di Indonesia: Perspektif Sosiologi Hukum
}

\author{
Agus Purnomo \\ Institut Agama Islam Negeri Ponorogo \\ agus_cholyl@yahoo.co.id
}

\begin{abstract}
Abstrak :
This paper presents a variety of public opinion on the application of the death penalty for perpetrators of acts of drugs in Indonesia. The study was focused on public dissent in response to the execution of the death penalty for drug crime and efforts to formulate effective criminal penalties for drug crimes. This paper study it from the angle of sociology of law in particular the theory of behaviorism and the theory of justice. In the perspective of sociology of law, a punishment device should include two things: first, it must accommodate public aspirations as the counterbalancing repay on the basis of an error rate of the perpetrator. Second, it must include the purpose of punishment, ie, maintain and preserve the unity of the community. Thus, the law must represent the public sense of justice. Hence the attitude and actions of the Indonesian people who chose the death penalty for criminal drug can be justified even in other countries have abolished the death penalty.

Tulisan ini menyajikan beragam pendapat masyarakat tentang penerapan hukuman mati bagi pelaku tindak narkoba di Indonesia. Kajian difokuskan pada perbedaan pendapat masyarakat dalam menyikapi eksekusi pidana mati bagi pelaku pidana narkoba dan upaya merumuskan hukuman pidana yang efektif bagi kejahatan narkoba. Tulisan ini mengkajinya dari sudut sosiologi hukum khususnya teori behaviorisme dan teori keadilan. Dalam perspektif sosiologi hukum, sebuah perangkat pemidanaan hendaknya mencakup dua hal, yakni: pertama, harus menampung aspirasi masyarakat yang menuntut pembalasan sebagai pengimbangan atas dasar tingkat kesalahan si pelaku. Kedua, harus mencakup tujuan pemidanaan, yakni memelihara dan mempertahankan kesatuan masyarakat. Dengan demikian, hukum harus mewakili rasa keadilan masyarakat. Karenanya sikap dan tindakan masyarakat yang memilih hukuman mati bagi pelaku tindak pidana narkoba dapat dibenarkan sekalipun di tempat lain hukuman mati ini dihapuskan.
\end{abstract}

Kata Kunci: Hukuman Mati; Narkoba; HAM

\section{Pendahuluan}

Pro-kontra hukuman mati bagi pelaku tindak pidana di Indonesia kembali marak diperbincangkan meski perdebatan serupa telah berulang kali terjadi pada tahun-tahun sebelumnya. Beberapa saat yang lalu, yaitu bulan Agustus 2016 hukuman mati bagi pelaku narkoba telah dilakukan setelah satu tahun sebelumnya, tepatnya tanggal 18 Januari 2015, hukuman serupa juga dijatuhkan kepada enam pelaku tindak pidana narkoba ${ }^{1}$ di

\footnotetext{
${ }^{1}$ Mereka terpidana mati adalah Marco Archer Cardoso Mareira (53 tahun warga negara Brasil), Daniel Enemua (38 tahun warga negara Nigeria), Ang Kim Soe (62 tahun warga negara Belanda), Namaona Dennis (48
} 
Nusakambangan dan Boyolali. ${ }^{2}$ Pada eksekusi pertama, gelombang protes terhadap pelaksanakan hukuman mati banyak diserukan oleh kelompok yang kontra terhadap persoalan tersebut.

Kelompok pegiat HAM misalnya, mereka memprotes kepada pelaksanaan hukuman mati yang dianggap bertentangan dengan Hak Asasi Manusia. Karenanya mereka menuntut pemerintah Indonesia untuk menghapus hukuman mati di Indonesia. Suara protes tidak hanya datang dari dalam negeri, Indonesia, melainkan juga dari negara tetangga yang warganya terkena pidana mati seperti Australia. Bahkan negara Kanguru tersebut mengancam untuk melarang warganya pergi ke Indonesia apabila Indonesia tetap menerapkan hukuman mati. Sikap yang beragam terhadap pelaksanaan hukuman mati sebenarnya terjadi sejak lama dan ada di beberapa negara. Di Indonesia misalnya, pelaksanaan hukuman mati secara hukum juga masih diakui dan diterapkan meskipun intensitasnya fluktuatif. Hingga 2006 tercatat ada 11 peraturan perundang-undangan yang masih memiliki ancaman hukuman mati, seperti: KUHP, UU Narkotika, UU Anti Korupsi, UU Anti terorisme, dan UU Pengadilan HAM. Daftar ini bisa bertambah panjang dengan adanya RUU Intelijen dan RUU Rahasia Negara. ${ }^{3}$

Begitu pula, pelaksanaan hukuman mati di Indonesia juga masih diterapkan. Dalam kurun waktu 10 tahun terakhir, tidak kurang dari 24 orang telah dihukum mati atas tindak pidana yang beragam. Di samping Indonesia, terdapat juga beberapa negara yang masih menerapkan hukuman mati, seperti Iran, Tiongkok, Arab Saudi, dan Amerika Serikat. Secara keseluruhan, sikap negara-negara terhadap hukuman mati adalah sebagai berikut: (a) 68 negara masih menerapkan hukuman mati termasuk Indonesia; (b) 88 negara telah menghapuskan hukuman mati untuk semua kategori kejahatan; (c) 1 negara telah menghapuskan hukuman mati untuk kejahatan biasa dan dikhususkan untuk kejahatan tertentu (luar biasa); (d) 30 negara melakukan moratorium untuk tidak menerapkan hukuman mati. ${ }^{4}$

Beragamnya sikap dan pendapat terhadap hukuman mati disebabkan oleh perbedaan alasan dan perspektif dalam melihat hukuman mati. Kelompok yang mendukung pelaksanaan hukuman mati berargumen bahwa: pertama, secara permanen hukuman atau pidana mati dapat menghilangkan para penjahat dari kehiduapan masyarakat yang memerlukan ketentraman dan ketenangan; kedua, pidana mati memiliki efek retributif yang dapat memberikan rasa keadilan khususnya kepada korban dan keluarganya yang mengalami penderitaan; ketiga, pidana mati memiliki dampak preventif bagi anggota masyarakat lain yang hendak melaksanakan kejahatan; keempat, pidana mati bukanlah tindakan yang dilarang oleh agama meskipun tetap memiliki persyaratan yang ketat. ${ }^{5}$

Sementara itu bagi kelompok yang menentang hukuman mati berpendapat sebaliknya. Di antara argumentasi yang dikemukakan adalah: pertama, pidana mati telah menegasikan kemungkinan bahwa manusia bisa berubah, bertaubat dan menyadari kesalahannnya untuk berbuat lebih baik; kedua, pidana mati tidak dapat dikoreksi bila terdapat kesalahan dalam penerapannya. Karenya, pidana mati sangat dimungkinkan dikenakan kepada orang yang sebenarnya tidak bersalah, bila ternyata dalam proses peradilan terdapat prosedur yang kurang tepat; ketiga, tindak pidana mati akan memberikan penderitaan yang kuat kepada keluarga terpidana mati karena secara psychologis keluarga akan dibebani dengan perasaan menunggu terhadap eksekusi pidana mati. ${ }^{6}$

tahun warga negara Malawi), Rani Andriani (warga negara Indonesia) dan Tran Thi Hanh (37 tahun warga negara Vietnam).

${ }^{2}$ Kompas, Senin 30 Maret 2015.

${ }^{3}$ http://id.m.wikipedia.org/wiki/Hukuman mati, diakses taggal 31 Maret 2015.

${ }_{4}$ Elmar Lubis, "Perkembangan Isu Hukuman Mati di Indonesia", Jurnal Opinio Juris, Vol. 4 Januari-April 2012, 33.

${ }^{5}$ Arie Siswanto, "Pidana Mati dalam Perspektif Hukum Internasional”, Refleksi Hukum, (April 2009), 10.

${ }^{6}$ Siswanto, "Pidana Mati., 11. 
Di samping itu, kelompok ini juga beralasan bahwa hukum internasional, dalam hal ini Deklarasi Universal HAM melarang pelaksanaan hukuman mati. Secara jelas, pada artikel 3 DUHAM dijelaskan bahwa "everyone has the right to life, liberty and security of person". Oleh karena setiap orang dijamin haknya untuk hidup, maka berarti bahwa seseorang tidak boleh menghilangkan nyawa orang lain. ${ }^{7}$ Berdasarkan argumen yang dikemukakan oleh masing-masing kelompok baik yang pro maupun kontra, maka alasan mereka dapat diidentifikasi menjadi 3 (tiga) macam, yakni alasan yuridis formal, alasan Hak Asasi Manusia (HAM), dan alasan keadilan. Dari identifikasi tersebut tulisan ini mengkaji kembali persoalan hukuman mati dari segi alasan masing-masing pihak, khususnya dari sisi teori sosiologi hukum. Secara rinci, persoalan difokuskan kepada perbedaan pendapat masyarakat dalam menyikapi eksekusi pidana mati bagi pelaku pidana narkoba dan upaya merumuskan hukuman pidana yang efektif bagi kejahatan narkoba di Indonesia. Dalam konteks ini, dipilihnya teori sosiologi hukum dalam mencermati persoalan hukum juga diperkuat dengan kenyataan bahwa hukum tidak seterusnya teratur, logis dan rasioanl, tetapi juga mengalami pergeseran ke arah paradigma yang nonsistemik (disorder of law). ${ }^{8}$

\section{Penerapan Hukuman Mati di Indonesia}

Hukuman mati di Indonesia sudah lama berlangsung, yaitu sejak bangsa Indonesia dijajah Belanda, hingga sampai sekarang masih tetap diberlakukan walaupun di Negara Belanda telah menghapuskan pidana mati mulai tahun 1987. KUHP (Wetboek Van Strafrecht) disahkan pada tanggal 1 Januari 1981. Menurut ahli-ahli pidana pada saat itu, dipertahankannya pidana mati karena keadaan khusus di Indonesia menuntut supaya penjahatpenjahat yang terbesar bisa dilawan dengan pidana mati. Dengan wilayah yang begitu luas dengan penduduk yang heterogen, alat Kepolisian Negara tidak bisa menjamin keamanan. ${ }^{9}$ Perbuatan-perbuatan atau tindak pidana yang diancam dengan pidana mati oleh KUHP, antara lain: Pasal 104, Pasal 111 ayat (2), Pasal 124 ayat (3), Pasal 140 ayat (3), Pasal 340, Pasal 365 ayat (4), Pasal 368 , Pasal 444 KUHP, Pasal 479 K ayat (2) dan Pasal 479 o ayat (2). Di samping itu hukuman mati di Indonesia juga dijelaskan dalam perundangan di luar KUHP, yaitu: a) Undang-Undang Nomor 5 Tahun 1997 tentang Psikotropika Pasal 59 ayat (2); b) Pasal 36 Undang-Undang Nomor 26 Tahun 2000 Tentang Pengadilan Hak Asasi Manusia; c) Pasal 2 ayat (2) Undang-Undang Nomor 20 tahun 2001 tentang Perubahan atas UndangUndang Nomor 31 Tahun 1999 tentang Pemberantasan Tindak Pidana korupsi; d) Pasal 6 Undang-Undang Nomor 15 tahun 2003 tentang Penetapan Peraturan Pemerintah Pengganti Undang-Undang Nomor 1 Tahun 2002 tentang Pemberantasan Tindak Pidana Terorisme; e) Undang-Undang Nomor 35 Tahun 2009 tentang Narkotika: Pasal 113 ayat (2), Pasal 114 ayat (2), Pasal 118 ayat (2), Pasal 119 ayat (2), Pasal 121 ayat (2), Pasal 144 ayat (2). ${ }^{10}$

Meski hukuman mati masih berlangsung dan belum dihapuskan di Indonesia, masyarakat berbeda pendapat dalam menanggapinya seiring dengan banyaknya negara-negara yang menghapuskan hukuman mati tersebut. Di satu pihak, ada kelompok masyarakat menyatakan dukungannya bahwa hukuman mati masih diperlukan di Indonesia terlebih lagi secara yuridis masih diakui. Sementara itu, di pihak lain terdapat kelompok masyarakat yang menginginkan agar hukuman mati dihapuskan. Mereka berargumen bahwa ketentuan hukuman mati yang berlaku di Indonesia ini tidak sesuai dengan prinsip dasar yang fundamental dari negara ini, yaitu UUD 1945.

\footnotetext{
${ }^{7}$ Siswanto, "Pidana Mati., 13.

${ }^{8}$ A. Mukthie Fadjar, Teori-Teori Hukum Kontemporer (Malang: Setara Press, 2014), 32.

${ }^{9}$ Lihat pula Departemen Hukum dan HAM RI, Jurnal Legislasi Indonesia. Vol. 4 No. 4, Desember 2007. Jakarta: Direktorat Jenderal Peraturan Perundang-undangan Departemen Hukum dan HAM, 44.

${ }^{10}$ Nata Sukam Bangun, Eksistensi Pidana Mati dalam Sistem Hukum Indonesia (Yogyakarta: Makalah Tidak Diterbitkan, 2014), 86.
} 
Menurut hasil survei nasional Indo Barometer yang diselenggarakan pada tanggal 15-25 Maret 2015, mayoritas publik di Indonesia, yakni sekitar 84,1 persen menyatakan setuju dengan hukuman mati bagi para pengedar narkoba. "Bagi mereka yang setuju, alasan yang banyak diungkap adalah bahwa narkoba merusak generasi muda (60,8\%), dan dapat menyebabkan efek jera (23,7\%)," demikian tutur Qodari. Adapun publik yang tidak setuju, alasan yang banyak diungkap adalah karena menurut mereka masih ada jenis hukuman lain yang lebih manusiawi $(36,2 \%)$, sementara hukuman mati justru merupakan pelanggaran terhadap hak asasi manusia $(28,4 \%) .{ }^{11}$ Sementara itu, lanjut Qodari, sebagian besar atau sekitar 84,6\% masyarakat Indonesia mendukung langkah Presiden Jokowi dalam menerapkan hukuman mati bagi pengedar narkoba, sedangkan yang tidak mendukung hanya 10,3 persen. Mayoritas publik $(86,3 \%$ ) menyatakan bahwa Presiden Jokowi sebaiknya tetap melanjutkan hukuman mati terhadap terpidana kasus narkoba, meski berimplikasi ada negara lain yang akan memutuskan hubungan diplomatik dan menghentikan kerjasama ekonomi dengan Negara Indonesia. ${ }^{12}$

Perbedaan pendapat tentang hukuman mati juga terjadi di lingkungan anggota Komisi Nasional Hak Asasi Manusia (KOMNASHAM). Sikap mereka terhadap hukuman mati ini juga terbagi dua, ada yang pro dan ada juga yang kontra. Hukuman mati di Indonesia harus dipertahankan atau dihapuskan. Bagi yang pro, hukuman terberat yang dijatuhkan oleh Majelis Hakim terpidana masih diperlukan terutama tindak pidana kejam. Bagi yang kontra, hukuman mati dianggap inskonstitusional atau bertentangan dengan konstitusi atau UndangUndang Dasar 1945, khususnya hak hidup bagi setiap warga negara. ${ }^{13}$

Bagi yang setuju, berargumen bahwa inkonstitusioanal atau tidaknya pidana mati sebenarnya telah terjawab dalam putusan Mahkamah Konstitusi pada permohonan pengujian materil Undang-Undang Nomor 22 tahun 1997 Tentang Narkotika terhadap Undang-Undang Dasar 1945. Judicial review tersebut diajukan oleh 4 (empat) terpidana mati kasus narkotika melalui kuasa hukumnya berkenaan dengan inkonstitusionalitas pidana mati yang termaktub di dalam Undang-Undang Nomor 22 tahun 1997 tentang Narkotika. Berdasarkan putusan Mahkamah Konstitusi tersebut, secara tegas dinyatakan bahwa ancaman pidana mati pada Undang-Undang Nomor 22 tahun 1997 tentang Narkotika tidaklah bertentangan dengan Konstitusi. Dengan demikian, dapat disimpulkan bahwa secara analogi, pidana mati bukanlah suatu tindakan inkonstituional. ${ }^{14}$

Di samping itu, pendukung hukuman mati lainnya juga membangun argumentasi bahwa secara yuridis hukuman mati di Indonesia adalah sah. Di antara bangunan argumentasi tersebut adalah: pertama, dengan menggunakan pendekatan secara harfiah (literal approach), dapat disimpulkan bahwa pelarangan adanya hukuman mati tidak dinyatakan dimanapun dalam UUD 1945. Oleh karenanya, kalimat "tidak dapat dikurangi dalam keadaan apapun" berdasarkan Pasal 28 I ayat (1), tidak dapat langsung diinterpretasikan sebagai pelarangan adanya hukuman mati. Perbandingan dengan Konstitusi Jerman dan Vietnam akan menunjukan bahwa pelarangan hukuman mati didukung secara tertulis dan terekspresikan secara harfiah dari pasal-pasal konstitusinya. Dengan tidak adanya ketentuan demikian dalam konstitusi Indonesia, hukuman mati sejalan dengan apa yang termuat di dalam UUD 1945.

Kedua, dengan menggunakan pendekatan teleologi (teleological approach), dapat ditemukan melalui pembukaan UUD 1945 bahwa tujuan daripada negara yaitu"melindungi segenap bangsa Indonesia dan seluruh tumpah darah Indonesia”. Bahkan sebagaimana laporan

\footnotetext{
${ }^{11} \mathrm{http}: / /$ www.pikiran-rakyat.com/nasional/2015/04/27/325117/rakyat-setuju-hukum-mati-bagi-pengedarnarkoba.

${ }^{12} \mathrm{http}: / / w w w . p i k i r a n-r a k y a t . c o m / n a s i o n a l / 2015 / 04 / 27 / 325117 /$ rakyat-setuju-hukum-mati-bagipengedar-narkoba.

${ }^{13}$ Departemen Hukum dan HAM RI, Jurnal Legislasi, 62.

${ }^{14}$ Bangun, Eksistensi Pidana Mati, 8.
} 
terakhir yang dilansir dari berbagai media, dinyatakan bahwa Indonesia memiliki 3,2 juta pemakai narkotika dengan angka kematian sekitar 15.000 jiwa per tahun atau secara rata-rata mengakibatkan 41 kematian setiap harinya, dikarenakan overdosis ataupun penggunaan narkotika yang terkait dengan infeksi AIDS. Negara mempunya kewajiban konstitusional untuk mencegah terjadinya kematian massal ini dan mencegah kemungkinan hilangnya generasi (lost generation) masa depan. Dengan demikian, perlindungan warga negara oleh Negara merupakan hal yang terpenting dan bahkan dapat dikatakan menjadi kewajiban yang lebih tinggi dibandingkan dengan tugas-tugas lainnya.

Ketiga, dengan menggunakan metode interpretasi sistematikal (systematical interpretation), maka akan jelas terlihat bahwa Pasal 28J ditempatkan dalam satu bab dengan artikel 28I, yang merupakan hasil amandemen mengenai Bab tentang Hak Asasi Manusia. Hal tersebut semakin meyakinkan bahwa Pasal 28J tersebut disusun dalam hubungan dan kaitannya dengan Pasal 28I. Hal tersebut tidak mempertimbangkan bahwa akan tepat bila diinterpretasikan bahwa restriksi terhadap pengimplementasian hak asasi manusia berdasarkan Pasal 28J terkait dengan lingkup hak-hak selain daripada Pasal 28I. ${ }^{15}$

Dukungan serupa terhadap pelaksanaan hukuman mati bagi tindak pidana berat juga didasarkan kepada beberapa alasan, yaitu: 1) hukuman mati merupakan tindakkan pembalasan dan pembentukan keadilan; 2) hukuman mati merupakan upaya efek jera dan preventif terhadap terjadinya tindak pidana; 3) hukuman mati juga ditujukan untuk menghilangkan ancaman terhadap keselamatan dan kepentingan umum ${ }^{16}$ Kontoversi tentang hukuman mati di Indonesia, seperti dijelaskan diatas, dapat dimengerti terlebih lagi dalam realitasnya hukuman mati tidak dihapuskan namun mengharuskan persyaratan yang cukup rumit dan implementasinya kurang jelas. Hal tersebut dapat dilihat dari beberapa kasus eksekusi mati yang tidak memiliki titik terang dalam pelaksanaannya. Sebagi contoh, sampai akhir tahun 2012, terdapat 133 terpidana mati yang belum dieksekusi di mana 19 tindak pidana narkoba menempati urutan tertinggi, yaitu 71 orang atau 53,38 \%. Sedangkan tindak pidana pembunuhan menempati urutan kedua yaitu sebanyak 60 orang atau 45,12\%, dan pada urutan ketiga ialah tindak pidana teorisme sebanyak 2 orang atau 1,50\%. Sebanyak 113 terpidana mati tersebut, Peninjauan Kembali (PK) dan permohonan grasinya kepada Presiden Repubpik Indonesia sudah ditolak, namun sampai kini belum dilakukan eksekusi.

\section{Hukuman Mati Bagi Pelaku Tindak Pidana Narkoba di Indonesia Pro Kontra Eksekusi Pidana Mati bagi Pelaku Pidana Narkoba}

Beberapa negara di dunia berbeda pendapat dalam menerapkan hukuman mati. Hampir sama dengan perdebatan tentang tata cara pelaksanaan hukuman mati, maka keberadaan hukuman matipun juga mengalami dinamika. Terdapat negara yang menolak pelaksanaan hukuman mati dan karenanya negara menghapuskan hukuman mati, sedangkan beberapa negara yang lain masih menerapkan pelaksanaan hukuman mati karena dianggap masih dibutuhkan.

Bagi kedua kelompok tersebut, baik yang mendukung maupun yang menentang, keduanya mendasarkan pendapatnya kepada alasan normatif maupun sosiologis. Indonesia misalnya, mayoritas publik atau sekitar 84,1 persen menyatakan setuju dengan hukuman mati yang diberikan kepada pengedar narkoba. "Bagi mereka yang setuju, alasan yang banyak diungkap adalah narkoba merusak generasi muda $(60,8 \%)$, dan dapat menyebabkan efek jera $(23,7 \%)$. Sedangkan publik yang tidak setuju, alasan yang banyak diungkap adalah masih ada

\footnotetext{
15 Pan Mohamad Faiz dan Mohamad Mova Al'Afghani," Perdebatan Konstitusionalitas Hukuman Mati” http://jurnalhukum.blogspot. com/ 2007/05/hukuman-mati-dan-narkotika.html.Narkotika dan Hukuman Mati. diakses 20 September 2015.

${ }^{16}$ Elmar I. Lubis, Perkembangan Isu Hukuman Mati, 36.
} 
jenis hukuman lain yang lebih manusiawi (36, 2\%) dan hukuman mati merupakan pelanggaran hak asasi manusia $(28,4 \%)$.

Di samping persoalan pijakan normatif tentang eksistensi hukuman mati yang beragam, perbedaan pendapat di masyarakat maupun otoritas hukum (pembentuk undang-undang, pengadilan, dan kejaksaan) dipengaruhi oleh berbagai faktor, seperti: pemahaman atas ajaran agama, latar belakang budaya, filosofi dan ideologi yang dianut oleh masyarakat, dan otoritas hukum tersebut. Demikian pula, latar belakang individu seperti gender, ras, tingkat ketaatan beragama, kelompok umur dan pandangan-pandangan pribadi tentang kejahatan tertentu juga mempengaruhi posisi dukungan atau penentangan terhadap hukuman mati. Kepentingan atau kebutuhan nasional masing-masing kawasan untuk terus-tidaknya mempertahankan hukuman mati bagi tindak pidana atau tindak kejahatan-kejahatan tertentu, juga pasti berbeda-beda.

Untuk kasus Indonesia, ketika kepentingan dan kebutuhan nasional dalam pandangan dan keyakinan masyarakat menghendaki hukuman mati untuk dipertahankan dan dilaksanakan atau dihapus dan dihentikan, keduanya harus disikapi secara obyektif. Ketika terdapat suara yang menghendaki dihapuskannya hukuman mati dari hukum positif Indonesia, mereka yang menyuarakannya perlu meyakinkan atau bahkan membuktikan secara empiris bahwa mayoritas masyarakat Indonesia juga memiliki pandangan yang sama dengan mereka. Akan tetapi, ketika mayoritas masyarakat menyuarakan hal yang sebaliknya, bahwa hukuman mati masih perlu dipertahankan dalam hukum positif Indonesia bagi pelaku kejahatankejahatan tertentu yang mengancam kepentingan masyarakat luas, seperti pelaku terorisme; bandar besar narkoba dan pembunuh berencana yang menghilangkan beberapa nyawa manusia. Realitas seperti inipun harus bisa diterima, sekaligus juga berhenti mencatat Indonesia sebagai negara yang tidak menghormati HAM karena masih mempertahankan hukuman mati. ${ }^{17}$

Berdasarkan uraian di atas, dapat dinyatakan bahwa perbedaan pandangan terhadap pelaksanaan hukuman mati khususnya bagi pelaku tindak pidana narkoba di sebabkan oleh peraturan yang multi penafsiran. Namun yang pasti secara formal hukuman mati masih diakui keberlakuannya di Indonesia meskipun dari waktu ke waktu diupayakan untuk meminimalisasi pelaksanaannya. Di samping itu, faktor-faktor di luar hukum, seperti kejenuhan masyarakat terhadap kejahatan narkoba yang kurang mendapat hukuman tegas, latar belakang agama masyarakat, dan kondisi social masyarakat adalah aspek lain yang sangat mempengaruhi masyarakat dan penegak hukum berbeda dalam melihat hukuman mati bagi pelaku tindak pidana narkoba di Indonesia.

\section{Rumusan Hukuman Pidana yang Efektif bagi Kejahatan Narkoba di Indonesia}

Kepala Badan Narkotika Nasional (BNN), Komjen Pol. Anang Iskandar menyatakan bahwa bahaya narkoba dan status Indonesia dalam darurat narkoba. Anang menyebutkan bahwa sekitar 50 orang meninggal setiap hari karena penyalahgunaan narkotika dan obat terlarang itu. Data BNN mencatat sekitar 4, 2 juta warga Indonesia menggunakan narkoba pada pertengahan $2014 .{ }^{18}$ Sekitar 50 orang meninggal setiap hari karena narkoba dan kerugian ekonomi maupun sosial mencapai Rp. 63 triliun per tahun. Oleh karena itu, Anang menilai bahwa hukuman mati dapat memberikan efek jera terhadap para pengedar norkoba.

BNN juga merilis bahwa kerugian atau dampak negatif dari narkoba meliputi kerugian materiil dan non materiil. Jumlah pengguna narkoba pada tahun 2013 misalnya, telah mencapai 43.767 orang. Jumlah tersebut tidak termasuk jumlah pengguna yang tidak tertangkap atau terdata di kepolisian. Artinya, jumlah pengguna sesungguhnya baik yang

\footnotetext{
${ }^{17}$ Asrul Sani, "Kontroversi Hukuman Mati".

${ }^{18} \mathrm{http}: / / w w w . c n n i n d o n e s i a . c o m / n a s i o n a l / 20150429202212-12-50148 /$ bnn-ingatkan-50-orang-meninggalsetiap-hari-karena-narkobal.
} 
terdata di kepolisian sebagai tersangka maupun yang tidak terdata akan mencapai jumlah yang lebih besar, ibarat gunung es. Berdasarkan hasil penelitian BNN bekerjasama dengan Puslitkes UI pada tahun 2011 tentang Survei Nasional Perkembangan Penyalahgunaan Narkoba di Indonesia, diketahui bahwa angka penyalahgunaan Narkoba di Indonesia telah mencapai $2,23 \%$ atau sekitar 4,2 juta orang dari total populasi penduduk. Fakta yang lebih memprihatinkan lagi, bahwa pengguna narkoba tersebut, sebagaimana data di kepolisian, terdistribusi ke dalam semua usia. ${ }^{19}$

Berdasarkan data BNN di atas, tampak bahwa dampak negatif dari penggunaan narkoba kini cukup serius. Fenomena tersebut akan memberikan implikasi terhadap sikap masyarakat yang melihatnya. Dengan menggunakan perspektif teori pilihan rasional -yang merupakan eksemplar dari behaviourisme- tindakan pemerintah dan masyarakat Indonesia yang bersikap tegas terhadap pelaku pidana narkoba dengan memberikan hukuman mati dapat dijelaskan. Menghadapi dampak pidana narkoba yang dilakukan oleh orang yang tidak bertanggung jawab, masyarakat Indonesia akan memilih hukuman yang tepat untuk diberikan kepada para pelaku tindak pidana narkoba yang sudah sangat merugikan masyarakat.

Hukuman mati bagi pelaku pidana narkoba adalah salah satu hukuman yang masih diterapkan di Indonesia di samping beberapa jenis hukuman lain. Meskipun kontroversial, hukuman mati di Negara ini bukanlah hukuman yang dilarang. Karena itu, dalam pandangan sosiologi hokum, khususnya teori pilihan rasional, sikap dan tindakan masyarakat Indonesia memilih menerapkan hukuman mati bagi pelaku tindak pidana narkoba dapat dibenarkan, sekalipun di negara lain pidana mati tersebut sudah ditiadakan atau dihapuskan. Teberapa daerah di wilayah Indonesia yang diyakini sebagai "hukum adat" dikalangan mereka. ${ }^{20} \mathrm{Di}$ Minangkabau, menurut pendapat konservatif dari Datuk Ketemanggungan dikenal hukum membalas, siapa yang mencurahkan darah juga dicurahkan darahnya. Adapun di Cirebon, penculik-penculik atau perampok wanita, apakah penduduk asli atau asing yang menculik atau menggadaikan pada orang Cirebon dianggap kejahatan yang dapat dipidana mati. Di Bali, pidana mati dikenakan bagi pelaku kawin sumban, begitu juga dengan beberapa daerah lain.

Dalam teori pilihan rasional, dijelaskan bahwa manusia akan memilih sesuatu yang rasional di antara pilihan-pilihan yang tersedia. Di bidang hukum masyarakat bisa memilih sebuah ketentuan di antara ketentuan yang ada sepanjang kesemuanya adalah legal. Pada kasus perilaku merokok misalnya, bahwa merokok adalah merugikan kesehatan. Akan tetapi akibat merokok, terdapat pabrik rokok yang menyerap banyak tenaga kerja dan memberikan pajak ke negara. Karena itu, pemerintah melakukan pilihan rasional untuk memberikan batasan-batasan tentang merokok meskipun tidak melarangnya. ${ }^{21}$ Sikap masyarakat terhadap hukuman pidana mati bagi pelaku tindak pidana narkoba dapat juga dijelaskan dari perspektif teori regresif frustasi Anthony Giddens, yang terkait erat dengan behaviorisme. Dalam teori tersebut dijelaskan bahwa masyarakat adakalnya dapat bersikap marah yang bersifat emosional dan memicu perilaku agresif manakala seseorang diberikan hukuman atas tindakannya, atau tidak diberikan penghargaan atau diberi penghargaan tetapi tidak cukup. ${ }^{22}$ Artinya seseorang hendaknya diberikan penghargaan atau hukuman sebanding dengan tindakannya biar tidak menyebabkan seseorang atau masyarakat emosional.

Dalam konteks penerapan hukuman mati bagi pidana narkoba, msyarakat akan bersikap emosional apabila menyaksikan pemberian hukuman kepada pelaku pidana narkoba yang tidak setimpal. Sementara itu, tindak pidana narkoba diyakini telah merugikan banyak

\footnotetext{
19 Jurnal Data Pencegahan dan Pemberantasan Penyalahgunaan dan Peredaran Gelap Narkoba (P4GN) Tahun 2013 Edisi Tahun 2014, 99.

${ }^{20}$ Syahruddin Husein, Pidana Mati Menurut Hukum Pidana Indonesia (Sumatera Utara: tp, 2003), 3.

${ }^{21}$ Fuadi, Teori-teori, 248.

${ }^{22}$ Fuadi, Teori-teori, 250.
} 
penduduk Indonesia. Karena itu, menyetujui untuk memberikan hukuman berat berupa hukuman mati bagi pelaku pidana narkoba adalah puncak emosional warga menyikapi fenomena tersebut.

Menurut Muladi, dalam perangkat tujuan pemidanaan tersebut harus tercakup dua hal, yaitu: pertama, harus sedikit banyak menampung aspirasi masyarakat yang menuntut pembalasan sebagai pengimbangan atas dasar tingkat kesalahan si pelaku; kedua, harus tercakup tujuan pemidanaan berupa memelihara solidaritas masyarakat, pemidanaan harus diarahkan untuk memelihara dan mempertahankan kesatuan masyarakat. ${ }^{23}$ Hukuman mati masih mewakili rasa keadilan yang dituntut oleh masyarakat. Selain unsur efek jera, efek preventif, pada dasarnya unsur pembalasan merupakan argumen kuat yang tidak dapat diabaikan yang merupakan jelmaan unsur rasa keadilan yang hidup dalam masyarakat. Sebagai negara yang demokratis, hukum yang berlaku harus dapat mencerminkan dan mewakili rasa keadilan yang hidup di dalam masyarakat. Oleh karena itu, Indonesia menilai bahwa hukum pidana mati masih tetap merupakan bagian dari hukum pidana Indonesia karena masyarakat Indonesia masih menginginkan adanya hukuman mati tersebut.

Berdasarkan uraian di atas, dapat dikatakan bahwa berdasarkan trend global penerapan hukuman mati -termasuk bagi pelaku tindak pidana narkoba- hendaknya ditinggalkan atau setidaknya diminimalisasi. Namun demikian, pada saat yang sama penetapan sebuah norma hukum di sebuah negara, seharusnya mempertimbangkan kehendak masyarakat sebagai bentuk penghormatan terhadap demokrasi. Dengan memadukan kedua cara berpikir tersebut, maka penerapan hukuman mati bagi pelaku tindak pidana di Indonesia masih relevan untuk dilaksanakan dengan tetap selektif dan melalui mekanisme yang benar. Hal tersebut didasarkan atas pertimbangan masyarakat menghendaki penerapan hukuman mati bagi pelaku pidana narkoba karena dinilai telah meresahkan. Mempertimbangkan kondisi masyarakat yang berbeda-beda antar masing-masing wilayah adalah penting guna menjamin efektivitas sebuah hukum seperti yang disarankan oleh penganut behaviorisme dan pilihan rasional.

\section{Kesimpulan}

Dengan mencermati uraian di atas, perbedaan pandangan terhadap pelaksanaan hukuman mati khususnya bagi pelaku tindak pidana narkoba di sebabkan oleh peraturan yang multi penafsiran. Di samping itu, factor-faktor di luar hukum, seperti kejenuhan masyarakat terhadap kejahatan narkoba yang kurang mendapat hukuman tegas, latar belakang agama masyarakat, dan kondisi social masyarakat adalah aspek lain yang sangat mempengaruhi masyarakat dan penegak hukum berbeda dalam melihat hukuman mati bagi pelaku tindak pidana narkoba di Indonesia. Dalam merumuskan regulasi, sebuah perangkat pemidanaan hendaknya mencakup dua hal, yakni: pertama, harus menampung aspirasi masyarakat yang menuntut pembalasan sebagai pengimbangan atas dasar tingkat kesalahan si pelaku. Kedua, harus mencakup tujuan pemidanaan berupa memelihara solidaritas masyarakat, pemidanaan harus diarahkan untuk memelihara dan mempertahankan kesatuan masyarakat. Dalam konteks demikian, ketika masyarakat Indonesia menghendaki penerapan hukuman mati bagi pelaku tindak narkoba, maka kehendak mereka tidak bisa dilarang. Hal itu karena, hukum harus mewakili rasa keadilan yang dituntut oleh masyarakat. Terlebih lagi, hukum pidana mati masih tetap merupakan bagian dari hukum pidana Indonesia, karena masyarakat masih menginginkan hukuman mati tersebut. Dengan demikian, dalam pandangan sosiologi hukum khususnya teori pilihan rasional, sikap dan tindakan masyarakat Indonesia memilih menerapkan hukuman mati bagi pelaku tindak pidana narkoba dapat dibenarkan. 


\section{Daftar Pustaka:}

\section{Buku dan Jurnal:}

Bangun, Nata Sukam. Eksistensi Pidana Mati dalam Sistem Hukum Indonesia. Yogyakarta: Makalah Tidak Diterbitkan, 2014.

Departemen Hukum dan HAM RI, Jurnal Legislasi Indonesia. Vol. 4 No. 4, Desember 2007. Jakarta: Direktorat Jenderal Peraturan Perundang-undangan Departemen Hukum dan HAM.

Fadjar, A. Mukthie. Teori-Teori Hukum Kontemporer. Malang: Setara Press, 2014.

Faiz, Pan Mohamad. "Teori Keadilan John Rawls”, Jurnal Konstitusi (April, 2009).

Fuadi, Munir. Teori-Teori Sosiologi Hukum. Jakarta: Kencana, 2011.

Gidden, Anthony. Teori Sosial, terj, Yudi Santoso. Yogyakarta: Pustaka Pelajar, 1987.

Husein, Syahruddin. Pidana Mati Menurut Hukum Pidana Indonesia. Sumatera Utara: tp, 2003.

Jurnal Data Pencegahan dan Pemberantasan Penyalahgunaan dan Peredaran Gelap Narkoba (P4GN) Tahun 2013 Edisi Tahun 2014.

Harian Kompas, Senin 30 Maret 2015.

Lubis, Elmar. "Perkembangan Isu Hukuman Mati di Indonesia", Jurnal Opinio Juris, Vol. 4 Januari-April 2012.

Mulyadi, Lilik. Bunga Rampai Hukum Pidana: Perspektif, Teoretis, dan Praktik. Bandung: PT Alumni, 2008.

Rawls, Jhon. Teori Keadilan, terj. Uzair Fauzan dan Heru Prasetyo. Yogyakarta: Pustaka Pelajar, 2006.

Siswanto, Arie. "Pidana Mati dalam Perspektif Hukum Internasional", Refleksi Hukum, (April 2009).

\section{Internet:}

Asrul Sani, "Kontroversi Hukuman Mati ", http://www.hukumonline. com/berita/ baca/lt54a692f2c80be/kontroversi-hukuman-mati-broleh--arsul-sani-Top of Form Bottom of Form.

http://id.m.wikipedia.org/wiki/Hukuman_mati.

http://www.cnnindonesia.com/nasional/20150429202212-12-50148/bnn-ingatkan-50-orangmeninggal-setiap-hari-karena-narkoba/

http://www.hukumonline.com/berita/baca/lt54a692f2c80be/kontroversi-hukuman-matiboleh--arsul-sani.

http://www.pikiran-rakyat.com/ nasional/2015/04/27/325117/rakyat-setuju-hukum-matibagi-pengedar-narkoba.

https://zackyubaid.wordpress.com/2010/01/19/pelaksanaan-hukuman-mati-di-indonesia-diber bagai-negara-sebagai-negara-hukum.

Pan Mohamad Faiz dan Mohamad Mova Al'Afghani," Perdebatan Konstitusionalitas Hukuman Mati" http://jurnalhukum.blogspot. com/2007/ 05/hukuman-mati-dannarkotika.html.Narkotika dan Hukuman Mati. 